\title{
STRATEGI NAFKAH DAN POLA PENGAMBILAN KEPUTUSAN RUMAH TANGGA PENGRAJIN GULA KELAPA
}

\section{Studi di Desa Ujung Genteng Kecamatan Ciracap Kabupaten Sukabumi Jawa Barat}

\author{
Living Strategy and Pattern of Household Decision Making Craftsmen Coconut Sugar \\ Study in Ujung Genteng Village, Ciracap District, Sukabumi, West Java \\ Rokhani*), La Ode Rauda A.U.Manarfa, AT. Alkhudri, dan Andi Ishak \\ Program Studi Sosiologi Pedesaan Fakultas Ekologi Manusia, Sekolah Pascasarjana IPB \\ *Email: rokhanisaid@yahoo.com
}

\begin{abstract}
This paper is intended to explain the livelihood strategies and patterns of household decision making coconut sugar producers. The analysis is built on the basis of the theory of 5 capital or assets, there are human capital, resourches, financial, physical, and social. Decision-making in the household coconut sugar producers were analyzed with a gender analysis framework consisting of: patterns of division of labor, decision-making and benefits, the use of resources. In methodology, this research is based on a qualitative approach. From the analysis of the five capital or asset management of the household, human capital (human capital) still needs to be improved. Families and communities coconut sugar producers utilize resources of individuals and families in the fifth utilizing capital (human, resourches, physical, financial, and social) so its great resiliace in the face of environmental changes (physical and social), especially facing the demands and obligations -liability of the company. Of the division of labor and decisionmaking, gender, household palm sugar producers tend to be balanced between the roles of men (husbands) and women (wives). Not only viewed from the allocation of time, but also the use of money from the sale of sugar.
\end{abstract}

Keywords: livelihood strategies, patterns of decision-making, domestic sugar producers

\begin{abstract}
ABSTRAK
Tulisan ini dimaksudkan untuk menjelaskan strategi penghidupan dan pola pengambilan rumah tangga membuat produsen gula kelapa. Analisis ini dibangun atas dasar teori dari 5 modal atau aset, ada modal manusia, Sumber, keuangan, fisik, dan sosial. Di produsen gula kelapa rumah tangga membuat keputusan-dianalisis dengan kerangka analisis gender yang terdiri dari: pola pembagian kerja, pengambilan keputusan dan manfaat, penggunaan sumber daya. Dalam metodologi, penelitian ini didasarkan pada pendekatan kualitatif. Dari analisis manajemen lima modal atau aset rumah tangga, modal manusia (human capital) masih perlu ditingkatkan. Keluarga dan masyarakat produsen gula kelapa sumber dari individu dan keluarga di ibukota kelima memanfaatkan (manusia, Sumber, fisik, keuangan, dan sosial) sehingga resiliace yang besar dalam menghadapi perubahan lingkungan (fisik dan sosial), terutama menghadapi tuntutan dan memanfaatkan kewajiban -liability perusahaan. Dari pembagian kerja dan pengambilan keputusan, jenis kelamin, produsen gula aren rumah tangga cenderung seimbang antara peran laki-laki (suami) dan perempuan (istri). Tidak hanya dilihat dari alokasi waktu, tetapi juga penggunaan uang dari penjualan gula.
\end{abstract}

Kata kunci: pola pengambilan keputusan, produsen gula dalam negeri, strategi penghidupan

\section{PENDAHULUAN}

\section{Latar Belakang}

Sumber nafkah petani di pedesaan sangat tergantung dengan kondisi sosial ekonomi budaya dan lingkungan setempat. Adaptasi yang mereka lakukan di bidang ekonomi sangat mudah terlihat. Oleh karena itu dengan memahami strategi nafkah, maka akan dapat dipahami kondisi sosial budaya masyarakat. Secara langsung maupun tidak langsung strategi nafkah terkait dengan pola hubungan dalam rumahtangga. Pengambilan keputusan dalam pola hubungan tersebut diduga dipengaruhi oleh sumber-sumber nafkah yang diperoleh oleh suami atau istri secara langsung. Secara tidak langsung ada hubungan antara strategi nafkah dengan pola pengambilan keputusan di dalam keluarga.

Di dalam tulisan ini akan dijelaskan strategi nafkah pengrajin gula kelapa dengan menggunakan kerangka analisis strategi nafkah dengan memasukkan 5 modal atau asset, yaitu modal 
manusia, alam, finansial, fisik, dan sosial (Chambers and Conway, 1991; de Haan, 2000; Ellis, 2000). Pengambilan keputusan dalam rumahtangga pengrajin gula kelapa dianalisis dengan kerangka analisis gender yang terdiri atas: pola pembagian kerja, pengambilan keputusan dan manfaat, atas penggunaan sumberdaya (Faqih, 1997; Megawangi, 1999; dan Rahmawati, 2003) .

Untuk menjawab kedua tujuan di atas, maka analisis historis digunakan sebagai pintu masuk yang sangat penting dari analisis secara keseluruhan. Oleh karena itu, tulisan ini terbagi atas beberapa bagian yaitu: (1) kondisi geo-demografis desa Ujung Genteng; (2) Tonggak-tonggak Perubahan Sosial dan Pola Hubungan Produksi Pembuatan Gula Kelapa; (3) Pengelolaan sumber-sumber nafkah dalam rumahtangga pengrajin gula kepala dan (4) Analisis Gender dalam rumahtangga pengrajin gula kelapa. Pada bagian akhir dari tulisan ini akan diuraikan beberapa hal terkait dengan aksiologis sebagai masukan dalam perbaikan ekonomi rumahtangga pengrajin gula kelapa.

\section{Metodologi Penelitian}

Penelitian dilakukan pada tanggal 15-18 Nopember 2014 pada saat field trip di Desa Ujung Genteng, Kecamatan Ciracap, Kabupaten Sukabumi, Provinsi Jawa Barat. Data yang dikumpulkan meliputi: (1) data primer diperoleh melalui wawancara mendalam dan observasi; (2) data sekunder bersumber dari Profil Desa Ujung Genteng Tahun 2013. Wawancara mendalam dilakukan dengan kepala desa, sekretaris Desa Ujung Genteng, tokoh masyarakat, pengrajin gula kelapa, pedagang pengumpul gula kelapa dan pengawas perkebunan Cigebang. Observasi dilakukan pada saat pengamatan lapangan kegiatan usaha pembuatan gula kelapa dan pada saat wawancara dengan memperhatikan kondisi tempat tinggal dan asset yang dimiliki petani. Data dianalisis dengan model interaktif mengikuti pendapat Miles dan Huberman (1992: 16). Dalam model ini, dilakukan reduksi data, penyajian data, dan penarikan kesimpulan, yang ketiganya merupakan suatu siklus untuk memperkuat pengambilan kesimpulan (Gambar 1).

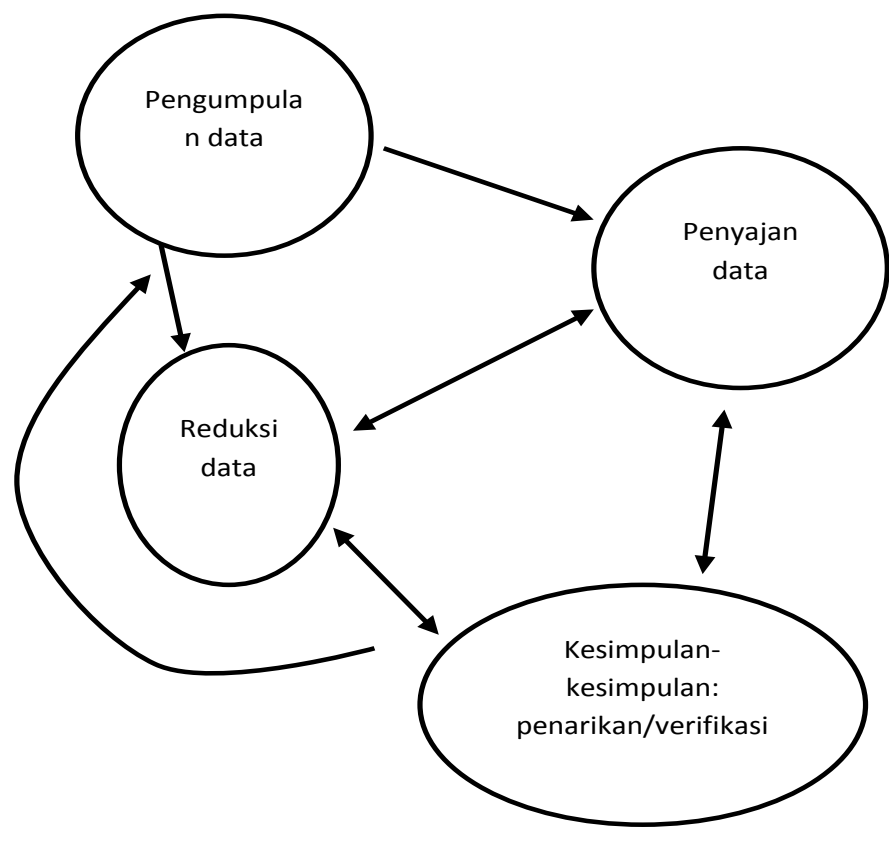

\section{Gambar 1 Analisis model interaktif}

\section{GAMBARAN UMUM}

\section{Kondisi Geo-demografis Desa Ujung Genteng}

Desa Ujung Genteng terletak di Kecamatan Ciracap, Kabupaten Sukabumi, Provinsi Jawa Barat. Letak Ujung Genteng \pm 23 km dari ibukota Kecamatan Ciracap, $170 \mathrm{~km}$ dari Ibukota Kabupaten (Sukabumi) dan $270 \mathrm{~km}$ dari ibukota Provinsi Jawa Barat (Bandung). Akses ke desa cukup mudah karena desa ini dilintasi jalan provinsi, sehingga dari Ciracap ke Ujung Genteng hanya perlu waktu sekitar 23 menit, dari Sukabumi 3,5 jam, dan dari Bandung 8 jam.

Secara administratif Desa Ujung Genteng berbatasan dengan Desa Gunung Batu, Kecamatan Waluran di Sebelah Utara, Samudara Hindia di Selatan, Desa Cikangkung, Kecamatan Surade di Timur, dan Desa Pangumbahan, Kecamatan Ciracap di Barat. Desa Ujung Genteng merupakan pemekaran Desa Gunung Batu sejak tahun 2008 berdasarkan Perda Kabupaten Sukabumi No. 8 tahun 2008.

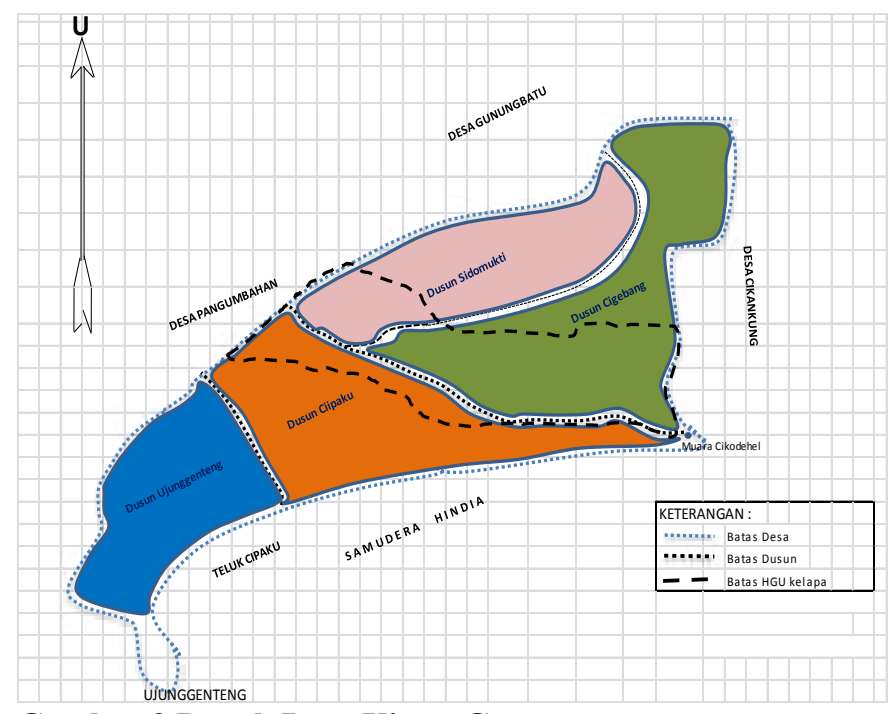

Gambar 2 Denah Desa Ujung Genteng

Desa Ujung Genteng terdiri dari empat Dusun yaitu: Ujung Genteng, Cipaku/Citarate, Cigebang dan Sidomukti. Keempat dusun tersebut memiliki kekhasan masing-masing. Dusun Cigebang misalnya merupakan konsentrasi pengrajin gula kelapa karena didukung dengan lokasi wilayah HGU kelapa yang dominan di dusun ini (Gambar 2).

Desa Ujung Genteng memiliki luas 1.870 ha. Sebagian besar lahan merupakan lahan pekarangan $(37,42 \%)$. Meskipun demikian terdapat juga lahan pemukiman, persawahan, perkebunan, dan hutan (Tabel 1). Daerah persawahan didominasi sawah tadah hujan yang dapat ditanami 2 kali setahun. Umumnya pola tanam yang diterapkan petani adalah padi-padi atau padi-palawija. Produktivitas sawah yang diusahakan penduduk relatif masih rendah yaitu antara 2-3 ton/ha/musim tanam. Padi hanya diusahakan untuk kebutuhan subsistensi.

Wilayah perkebunan didominasi oleh perkebunan kelapa yaitu sekitar 200 ha $(57,14 \%)$ dari total 350 ha lahan perkebunan. Luasnya lahan perkebunan kelapa tidaklah mengherankan karena daerah ini merupakan wilayah eks PTPN Cigebang. 
Tabel 1. Jenis peruntukan lahan di Desa Ujung Genteng.

\begin{tabular}{lrc}
\hline \multicolumn{1}{c}{ Peruntukan lahan } & \multicolumn{2}{c}{ Luas lahan } \\
& Ha & $\%$ \\
\hline Pemukiman & 299,8 & 16,03 \\
Persawahan & 250,0 & 13,37 \\
Perkebunan & 350,0 & 18,71 \\
Kuburan & 5,3 & 0,28 \\
Pekarangan & 699,8 & 37,42 \\
Hutan & 260,4 & 13,92 \\
Prasarana umum (jalan, sekolah, & 4,90 & 0,26 \\
pasar, fasilitas umum lainnya) & & \\
\hline \multicolumn{2}{c}{ Total } & $1.870,2$ \\
\hline
\end{tabular}

Sumber: Profil Desa, 2013.

Jumlah penduduk Desa Ujung Genteng pada tahun 2013 mencapai 4.569 jiwa dengan jumlah Kepala Keluarga (KK) adalah $1.277 \mathrm{KK}$. Jumlah penduduk laki-laki sebanyak 2.381 orang lebih banyak daripada perempuan sebanyak 2.188 orang (sex ratio: 1,09). Penduduk di Desa Ujng Genteng didominasi oleh penduduk berusia produktif (15-60 tahun). Komposisi penduduk menurut jenis kelamin dan umur ditampilkan pada Gambar 3.

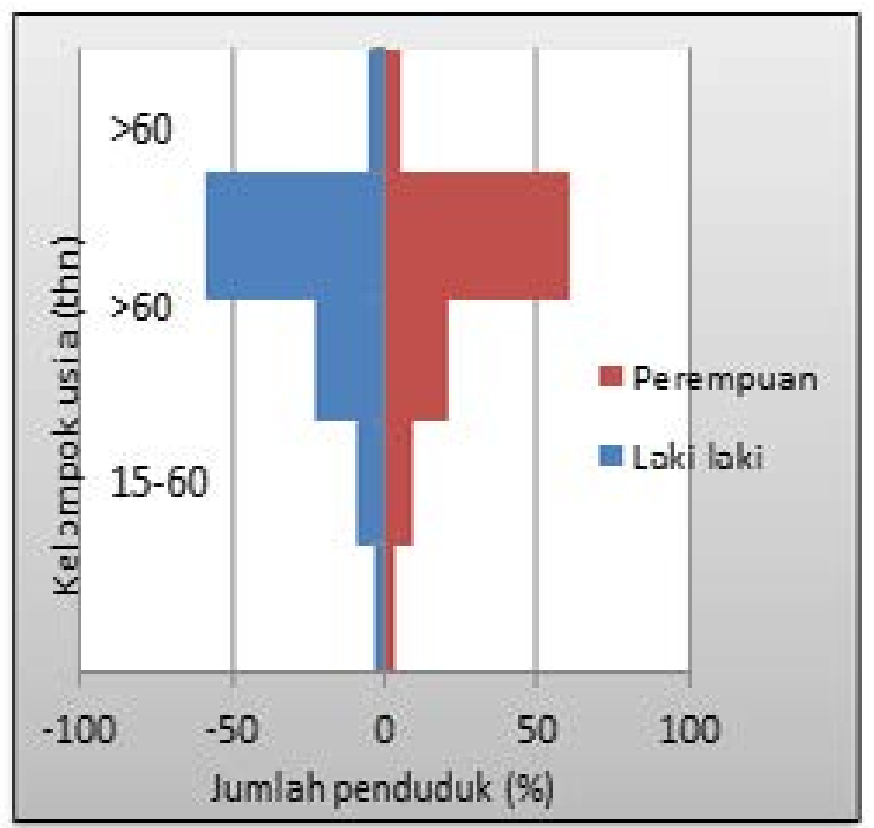

Gambar 3 Piramida penduduk Desa Ujung Genteng

\section{PEMBAHASAN}

\section{Tonggak-tonggak Perubahan Sosial dan Pola Hubungan Produksi Pembuatan Gula Kelapa}

Nama Ujung Genteng berasal dari Ujung Gunting. Penamaan ini didasarkan pada posisi Ujung Genteng yang berada di ujung salah satu sudut Pulau di Jawa Barat yang berbentuk gunting dan mengapit Teluk Pelabuhan Ratu. Bagian ujung gunting bawah disebut Ujung Genteng, sedangkan bagian Ujung Gunting atas berada di Ujung Kulon. Secara historis Ujung Genteng telah mengalami lima tonggak perubahan sosial, yaitu: (1) era kerajaan; (2) era kolonial; (3) era orde lama; serta (4) era orde baru dan reformasi. Pada masa kerajaan Hindu, baik kerajaan Agrabinta (Awal Masehi), kerajaan Taruma Nagara maupun ketika masa kerajaan Sunda Pajajaran, Ujung Genteng berfungsi sebagai pelabuhan utama.

Masa penjajahan Belanda, Ujung Genteng berperan sebagai daerah perkebunan kelapa dan karet. Pemerintah Hindia Belanda mendatangkan para pekerja sekitar tahun 1911-1920an yang pada umumnya berasal dari Cilacap dan Kebumen (Jawa Tengah). Inilah awal kedatangan orang Jawa di Sukabumi Selatan yang kemudian membentuk perkampunganperkampungan.

Pada era orde lama, Ujung Genteng dijadikan sebagai pangkalan militer TNI. Perkebunan-perkebunan warisan pemerintah kolonial Belanda dinasionalisasi menjadi PTPN. Hal ini tetap bertahan sampai dengan masa Orde Baru. Antara tahun 1945 - 1980 perkebunan dan hasilnya menjadi bagian penting yang mendukung perekonomian di Ujung Genteng. Sampai dengan tahun 1980-an, gerak penduduk relatif bersifat statis dan terkonsentrasi di area perkebunan. Pembangunan infrastruktur jalan masih belum memadai. Jarak tempuh Ujung Genteng - Sukabumi pun terasa sangat jauh, di mana untuk mencapai ke sukabumi harus dilalui dalam waktu 3-5 hari PP. Saat ini Ujung Genteng - Sukabumi sudah dapat ditempuh dalam waktu sekitar 7 jam PP.

Pada tahun 1985, industri perkebunan nasional di Ujung Genteng mulai mengalami kemunduran. Namun ekonomi pesisir tumbuh dan menjadi pemain utama yang menggerakkan roda perekonomi masyarakat Ujung Genteng. Wilayah pesisir didominasi oleh para nelayan pinggir, pancing, dan jaring betot. Mereka umumnya berasal dari Pati, Pekalongan, Cirebon, Indramayu, dan Pelabuhan Ratu. Dari sinilah kemudian berkembang perkampungan pesisir Jawa, sebagai kelanjutan dari perkampungan-perkampungan Jawa di sektor perkebunan. Hal ini menyebabkan para pekerja kebun mengubah strategi nafkah dari petani kebun menjadi nelayan.

Kemunduran usaha sektor perkebunan negara telah menarik para pengusaha yang melihat peluang usaha yang tersisa dari sektor perkebunan. Mereka mengambil alih usaha perkebunan tersebut dengan sistem Hak Guna Usaha (dalam masa 30-35 tahun). Sejak 1985 sampai dengan saat ini telah terjadi dua kali pengalihan HBU di lahan eks-PTPN, yaitu PT. Brajatama dan yang terakhir PT. Bumi Lestari Abadi (BLA). Tonggaktonggak historis perubahan sosial di Desa Ujung Genteng sejak jaman kerajaan sampai dengan saat ini terlihat pada matriks sebagai berikut (Tabel 2).

Dari Tabel 2 di bawah terlihat bahwa faktor ekonomi selalu menjadi faktor pendorong dominan yang menentukan perubahan sosial di Desa Ujung Genteng

Sistem kerjasama antara PT. BLA (pemegang HGU saat ini) dengan masyarakat (pengrajin gula kelapa) di Desa Ujung Genteng seluas 200 ha dilakukan untuk mengoptimalkan potensi perkebunan kelapa dengan memproduksi gula kelapa. Penduduk mulai membuat gula kelapa pada tahun 1999. Salah satu tokohnya adalah "Bapak Bisri" yang belajar membuat gula kelapa dari orang Cilacap yang tinggal di Pangumbahan. 


\section{Tabel 2. Tonggak-tonggak historis dan perubahan sosial di Desa Ujung Genteng}

\begin{tabular}{|c|c|c|c|}
\hline Pashish if arth & Thisit & Pavbihe whil & 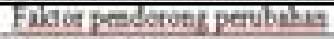 \\
\hline Fandu Hidy & 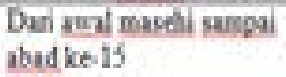 & 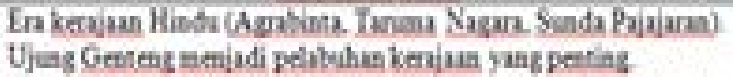 & Povik-thomsin \\
\hline Misi Kablit Brli=di & $1911-1920$-an & 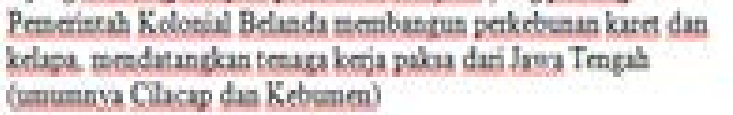 & 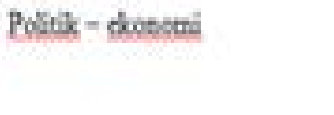 \\
\hline
\end{tabular}

\begin{tabular}{|c|}
\hline Mu OrdeLm \\
\hline $\begin{array}{l}\text { Mar onde lindon } \\
\text { Retomis: }\end{array}$ \\
\hline
\end{tabular}

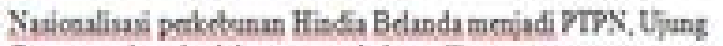

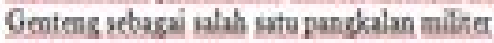

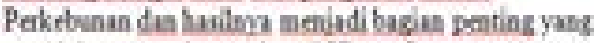

Potra-kraman

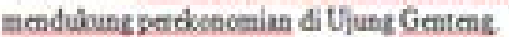

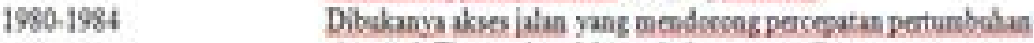

Dhowint

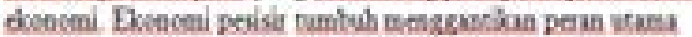

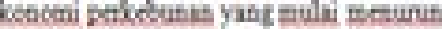

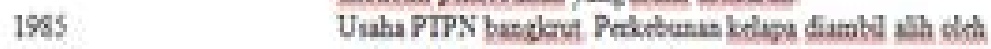

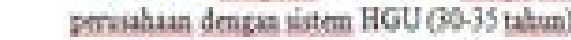

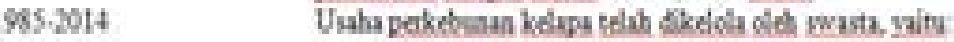

PT Bainisis

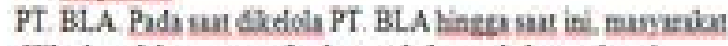

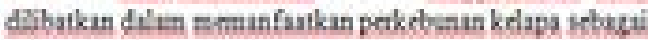

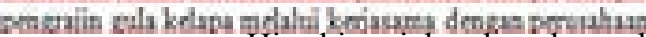

Dari Tabel 2 di atas terlihat bahwa faktor ekonomi selalu menjadi faktor pendorong dominan yang menentukan perubahan sosial di Desa Ujung Genteng

A sosial pada pola produksi gula kelapa dikuasai oleh PT. BLA (strata atas), lapisan kedua adalah pedagang pengumpul (strata menengah), dan pengrajin gula kelapa (strata bawah) (Gambar 5).

Sistem kerjasama antara PT. BLA (pemegang HGU saat ini) dengan masyarakat (pengrajin gula kelapa) di Desa Ujung Genteng seluas 200 ha dilakukan untuk mengoptimalkan potensi perkebunan kelapa dengan memproduksi gula kelapa. Penduduk mulai membuat gula kelapa pada tahun 1999. Salah satu tokohnya adalah "Bapak Bisri" yang belajar membuat gula kelapa dari orang Cilacap yang tinggal di Pangumbahan. Kerjasama antara PT. BLA dengan pengrajin gula kelapa dilakukan dengan dua cara. Pertama, menggunakan sistem bagi hasil. Pengrajin menyerahkan hasil produksi gula kelapa sebanyak $1 \mathrm{~kg} /$ pohon/bulan kepada perusahaan. Umumnya pengrajin mengusahakan 60 pohon kelapa, sehingga mereka harus menyerahkan $60 \mathrm{~kg}$ gula kelapa kepada PT. BLA setiap bulan. Penyerahannya setiap tanggal 1-6 bulan berjalan. Kedua, menjual hasil produksinya selama 20 hari sebanyak 10 $\mathrm{kg} /$ hari antara tanggal 7-25 bulan berjalan, sehingga total yang harus dijual ke PT. BLA sebanyak $200 \mathrm{~kg} / \mathrm{bulan}$. Perjanjian dilakukan secara tidak tertulis. Kadang-kadang, perusahaan membuat edaran kepada para pengrajin untuk mengingatkan kembali perjanjian mereka terkait dengan penyerahan hasil produksi dan penjualan gula kelapa (Gambar 4).

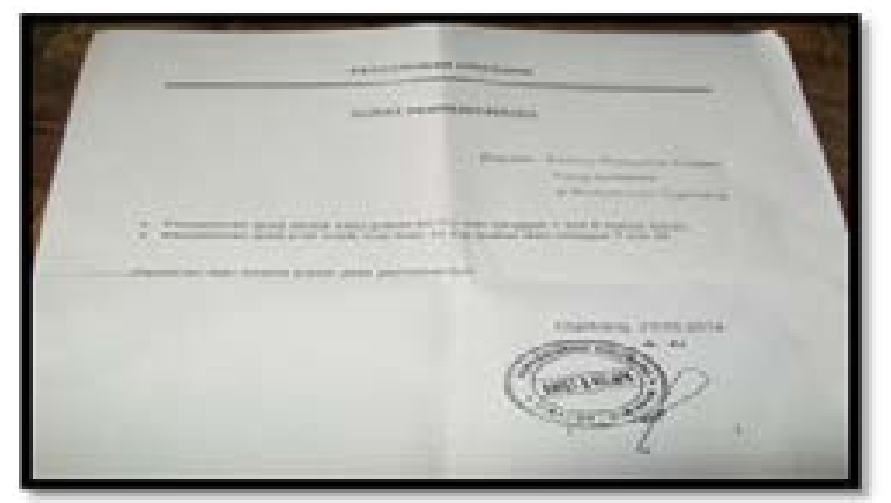

Gambar 4 Surat Pemberitahuan Kewajiban Penjualan Produksi kepada PT. BLA

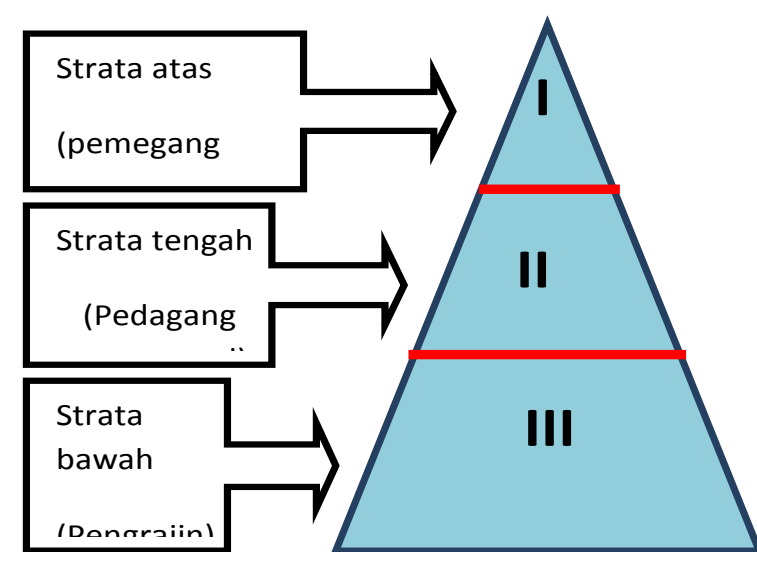

Gambar 5 Stratifikasi pola produksi gula kelapa di Dusun Cigebang - Ujung Genteng.

Dalam stratifikasi masyarakat pada Gambar 5, posisi pengrajin kelapa (strata III) terletak pada dasar piramida, menempatkan mereka pada posisi terlemah dalam siklus produksi gula kelapa. Jumlah mereka saat ini di Dusun Cigebang sekitar 30 KK, 21 KK diantaranya juga bertani padi sawah, namun demikian usaha pembuatan gula kelapa tetap merupakan usaha utama.

Pengrajin gula kelapa umumnya selalu tergantung dengan para pedagang pengumpul (bos) dalam penyediaan modal produksi dan juga "terpaksa" menyerahkan hasil produksi gula kelapa mereka (dalam sistem bagi hasil maupun penjualan dengan harga yang lebih murah dari harga pasar dalam volume yang tetap) kepada pihak perusahaan. Jika kewajiban pengrajin kepada perusahaan tidak terpenuhi, maka "ijin produksi" mereka di lahan perusahaan akan dicabut dan dialihkan ke

132 Rokhani. et al. Strategi Nafkah dan Pola Pengambilan Keputusan Rumahtangga Pengrajin Gula Kelapa (Studi di Desa Ujung Genteng Kecamatan Ciracap Kabupaten Sukabumi Jawa Barat) 
pengrajin yang lain. Kerjasama dengan PT. BLA merugikan pengrajin, karena mereka harus menjual gula kelapa rendah antara Rp. $1.500-2.500$ per kg.

Pedagang pengumpul pada strata II memanfaatkan surplus (kelebihan) produksi pengrajin gula kelapa setelah kewajiban pengrajin kepada perusahaan terpenuhi. Pemberian modal kepada pengrajin merupakan strategi pedagang pengumpul melakukan kerja sama dengan memanfaatkan kebutuhan pengarajin gula kelapa, untuk membeli gula kelapa dengan harga yang lebih murah dibandingkan harga pasar namun sedikit lebih tinggi dari harga gula yang dijual pengrajin ke PT. BLA. Pembayaran utang pengrajin hanya dihitung utang pokoknya saja, tanpa bunga.

\section{Pengelolaan Sumber-sumber Nafkah dalam Rumah Tangga Pengrajin Gula Kelapa}

Di dalam melakukan strategi nafkah, rumahtangga pengrajin gula kelapa tidak terlepas dari berbagai modal (aset) yang mereka miliki, yaitu modal manusia (human capital), modal alamiah (natural capital), modal finansial (financial capital), modal fisik (physical capital) dan modal sosial (social capital). Sebelum menjelaskan bagaimana kelima modal ini mempengaruhi strategi nafkah pengrajin gula kelapa, akan digambarkan terlebih dahulu proses pembuat gula kelapa.

Usaha pembuatan gula kelapa dilakukan secara tradisional dengan teknologi yang masih sederhana. Nira sebagai sumber bahan baku gula kelapa diperoleh dengan menyadap yang dimulai dengan cara mengikat manggar, lalu memotong bunga kelapa (manggar) untuk diambil niranya. Semula nira ditampung menggunakan bambu (bumbung), namun akhirakhir ini digantikan dengan jaligen karena sifat bambu yang dinilai kurang higienis, mudah jatuh dari pohon dan pecah. Nira hasil sadapan langsung diolah di atas tungku dengan waktu antara 4-5 jam, bahkan di musim penghujan proses pemasakan memelukan tambahan waktu 1 sampai 2 jam

Setelah nira di atas tungku mengental, barulah wajan (kuali) diangkat, kemudian dilanjutkan pengadukan (pengguisan) yang dilanjutkan dengan pencetakan, pengemasan lalu penjualan. Proses pencetakan dilakukan dengan alat cetak yang terbuat dari bambu. Proses pengemasan di plastik berisi 10 buah kelapa, dengan berat rata-rata $1 \mathrm{~kg}$ per unit. Bahan bakar untuk membuat gula kepala adalah berbagai jensi kayu, daun kelapa yang mengering dan sekam, Namun akhir-akhir ini pengrajin jarang menggunakan kayu bakar karena diilai lebih mahal. Proses pembuatan gula kelapa terlihat pada Lampiran 1 .

\section{Identifikasi Human Capital}

Penduduk Dusun Cigebang yang menjadi pengrajin gula kelapa belajar membuat gula dari para pendatang di Cigebang. Mereka belajar dengan mengamati sekaligus membantu para pengrajin seperti mencuci bumbung (wadah yang terbuat dari bambu untuk menampung nira kelapa), memasak nira dari pohon kelapa hingga mencetaknya. Proses belajar membutuhkan waktu sekitar 1 bulan.

Sebagian besar pengrajin gula kelapa tidak menamatkan pendidikan formalnya di tingkat Sekolah Dasar (drop out). Namun penyadap yang usianya masih relatif muda ( 25 tahun) umumnya menamatkan pendidikannya hingga bangku Sekolah Menengah Pertama (SMP). Selama menjadi pengrajin belum pernah mendapatkan pendidikan dan pelatihan dari instansi terkait dalam industri rumahtangga gula kelapa. Kondisi ini menyebabkan sumberdaya manusia (human capital) pengrajin gula kelapa relatif rendah.

\section{Identifikasi Natural Capital}

Rata-rata pengrajin gula kelapa menyadap 60 pohon kelapa (1 paket) milik perkebunan yang dikelola dengan sistem bagi hasil. Fakta di lapangan, dari 60 pohon kelapa (disebut satu paket), seringkali tidak seluruhnya produktif, sekitar 10 pohon tidak dapat disadap (istilah setempat disebut "paleg"), sehingga rata-rata pengrajin menyadap sebanyak 50 pohon kelapa.

Sebagian pengrajin memperoleh pohon kelapa tidak secara langsung dari tangan pertama (perkebunan), namun "membeli" dari penyadap lain. Biayanya hingga mencapai 4 juta rupiah (untuk mengganti biaya tenaga kerja, pembuatan gubug atau istilah setempat disebut "heunca", dan seluruh peralatan menyadap). Pohon kelapa yang disadap adalah kelapa hibrida (varietas Kina) yang ditanam tahun 1985/1986 (sekaran berumur sekitar 30 tahun).

Penghasilan dari membuat gula kelapa dirasakan pengrajin relatif tidak mencukupi kebutuhan rumah tangga. Untuk menambah penghasilannya, pengrajin menanam berbagai jenis pisang (tanduk, kapas, uli) di sela-sela tanaman kelapa dan singkong (Gambar 6). Pisang yang dipanen dijual dengan harga sekitar Rp. 20.000,- per tandan. Selain pisang, pengrajin kelapa juga menanam singkong dan ubi talas di sela-sela pohon kelapa untuk kebutuhan konsumsi sendiri dan sebagian dibagikan kepada para tetangganya.

Sekitar $70 \%$ pengrajin gula kelapa juga menanam padi di sawah tadah hujan maupun di lahan milik perkebunan dengan teknologi yang sederhana (sistem tugal) seperti terlihat pada Gambar 7. Penanaman padi di sawah tadah hujan dilakukan 1-2 kali setahun, tergantung ketersediaan air, sedangkan padi di lahan kering hanya ditanam sekali setahun. Hasilnya untuk memenuhi kebutuhan pangan sehari-hari. Pada masa paceklik (musim kemarau), pengrajin mengolah singkong menjadi tiwul ("inter") dan ubi talas sebagai bahan pangan. Kondisi sumberdaya alam secara umum relatif sedang.

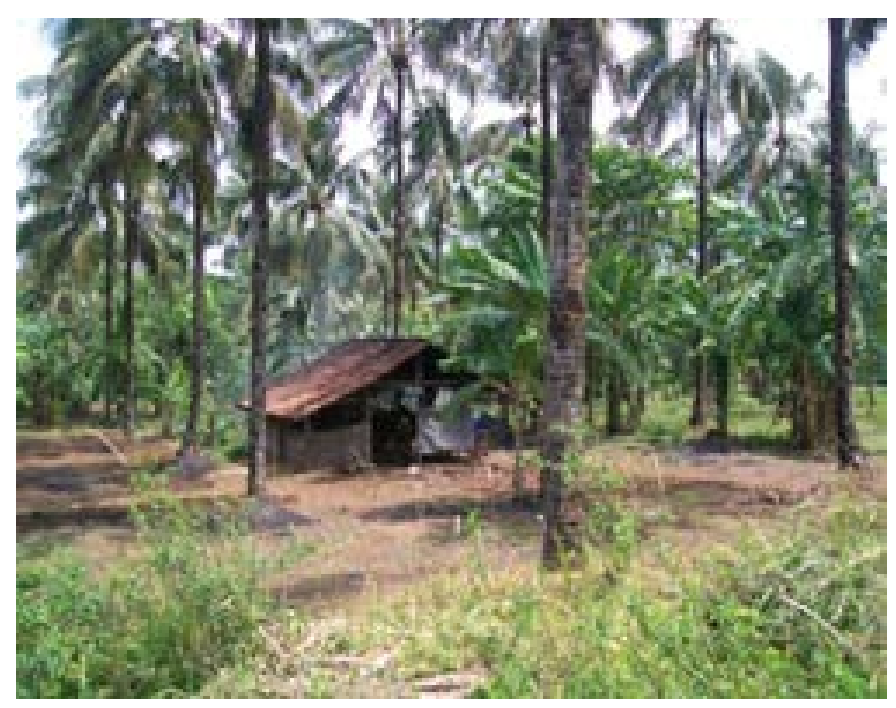

Gambar 6 Penanaman pisang di antara perkebunan kelapa 


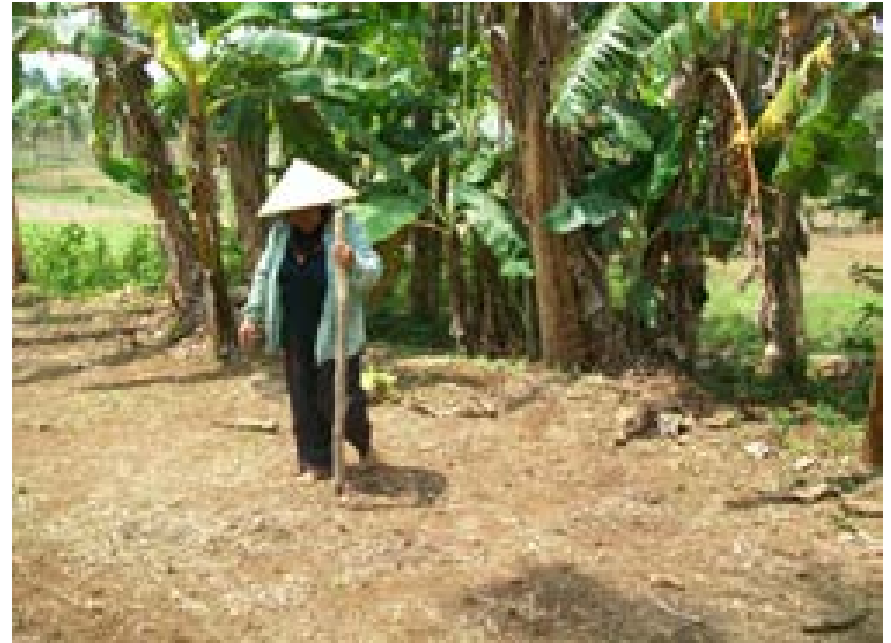

Gambar 7 Pengrajin menugal lahan untuk penanaman padi gogo

\section{Identifikasi Financial Capital}

Proses menyadap dan membuat gula dilakukan setiap hari di gubug (istilah setempat disebut "heunca"). Untuk menghemat proses pemasakan nira sebelum dicetak, petani tidak menggunakan kayu bakar saja sebagai bahan bakar, namun mnggunakan sekam. Sekam diperoleh dengan cara membeli di penggilingan padi (huller) di dalam Dusun Cigebang, dengan harga Rp 15.000,- per karung yang diterima di gubug (tempat pembuatan gula) dengan diantar jasa ojeg.

Peralatan yang dipergunakan untuk menyadap sangat sederhana, berupa, "bedog" untuk membuat lubang pada batang pohon kelapa serta memotong bunga kelapa (manggar), serta"jaligen“" kapasitas 5 liter untuk menampung nira menggantikan bumbung (terbuat dari bambu). Penggantian bumbung dengan jaligen disebabkan karena penggunaan bumbung dinilai kurang higienis, serta mudah pecah. Untuk memasak nira dipergunakan wajan (kuali) ukuran 40 yang dibeli.

Berbeda dengan pedagang pengumpul yang mengakses modal dari bank, sebagian besar penyadap memperoleh modal dari pedagang pengumpul (bos). Sementara sebagian kecil penyadap menggunakan modal sendiri dari hasil panen padi dan palawija Bantuan atau hibah (baik berupa uang maupun peralatan) belum pernah diperoleh pengrajin dari pihak lain termasuk pemerintah.

Usaha menyadap gula kelapa merupakan sumber penghasilan utama. Usaha ini menjadi andalan untuk biaya memperbaiki rumah, uang muka pembelian sepeda motor, dan pengeluaran yang relatif besar untuk menghadiri hajatan dan biaya makan sehari-hari. Bagi sebagian pengrajin yang tidak memiliki sumber pendapatan lain, usaha pembuatan gula kelapa relatif tidak mencukupi kebutuhan rumah tangga.

Selain sumber pendapatan selain dari pembuatan gula kelapa, sebagian rumah tangga pengrajin memiliki sumber penghasilan dari remitten yang dikirimkan anaknya yang bermigrasi ke Jakarta baik sebagai pembantu rumahtangga, babby sitter hingga karyawan pabrik. Umumnya yang melakukan migrasi adalah anak yang drop out sekolah dari SLTP. Rata-rata pendapatan keluarga dari remitten sebesar Rp 500.000 per bulan.
Alat-alat (perlengkapan) dan "heunca" yang digunakan dalam pembuatan gula kelapa cukup mahal, merupakan biaya tetap (fix cost) yang mencapai sekitar 7 juta rupiah (Tabel 3). Proses pembuatan gula kelapa membutuhkan biaya tenaga kerja dan bahan-bahan (variable cost). Analisis usaha pembuatan gula kelapa disajikan pata Tabel 4 .

\section{Tabel 3. Biaya tetap (fix cost) dalam pembuatan gula kelapa di Cigebang (1 paket)}

\begin{tabular}{|c|c|c|c|c|c|c|}
\hline 4 & Antripat & thin & HA & Enilen & Brith & Nupчnta \\
\hline L & In|⿴囗十 & 19 & 1 & $\lim ^{n}$ & Mmin & 76 \\
\hline 2 & Thin & H & 1 & $16 \%$ & IM⿻上丨 & I \\
\hline 1 & $8 y$ & $\mathrm{ht}$ & $i$ & AH & ENII & 1 \\
\hline I & tish by & bi & \pm & 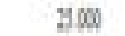 & yow & I \\
\hline 1 & Foth be & nit & 1 & HW & 5M & i \\
\hline 1 & bnal & his & 1 & 10 & in & $\rrbracket$ \\
\hline is & Mrak & nis & j & $\$ \mathrm{Wi}$ & 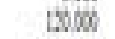 & $i$ \\
\hline 1 & His ind & hit & W & $M$ & $1 \%$ m. & 1 \\
\hline 1 & Atin Bat & hit & 4 & $1 \mathrm{~W}$ & Hin & 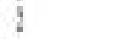 \\
\hline 14 & Finglwh & hat & 1 & $\$ W$ & sim & 1 \\
\hline II & Pandithi & hit & 1 & ISW & 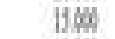 & 1 \\
\hline \multirow[t]{2}{*}{ II } & Awhy & his & 1 & $1 \mathrm{ND}$ & $10 \mathrm{a}$ & 2 \\
\hline & IH & 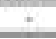 & 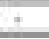 & $=$ & 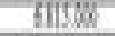 & I \\
\hline
\end{tabular}

Tabel 4. Analisis usaha pembuatan gula kelapa per 1 paket (60 pohon) per hari (variable cost)

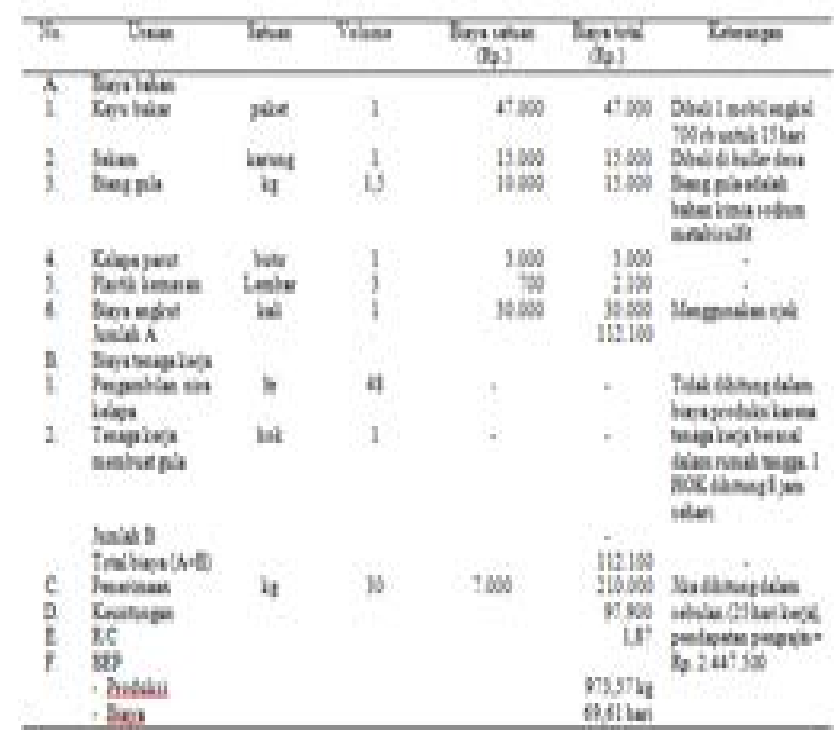

Pada Tabel 4 diketahui bahwa penerimaan pengrajin gula kelapa 1 bulan sebesar Rp, 2.447.500. Bila dibandingkan dengan UMK Kabupaten Sukabumi sebesar Rp. 1.565.922, maka angka relatif lebih tinggi (SK Gubernur Jawa Barat No. 561/Kep.1636-Bangsos/2014). Namun pembuatan gula kelapa dilakukan bersama-sama oleh suami-istri dalam satu keluarga, sehingga efisiensinya rendah. Jika dibagi dua, maka jumlah pendapatan pengrajin gula kelapa per orang lebih rendah (Rp. 1.223.750) daripada UMK.

Ukuran ekonomi seorang penyadap dikatakan berhasil apabila mampu menabung (biasanya dalam bentuk tenak domba dan sapi) dan tidak memiliki hutang. Secara umum modal finansial penyadap termasuk cukup tersedia dengan menjalin hubungan (jaringan) dengan para pedagang pengumpul (bos). 


\section{Identifikasi Physical Capital}

Umumnya pengrajin sudah berkeluarga dan tinggal di rumah relatif sederhana, kecuali pasangan muda yang baru menikah (contoh: Herman, 25 tahun) masih tinggal bersama orangtuanya. Sebanyak 19 keluarga di Dusun Cigebang telah mengikuti arisan WC. Besar arisan sebanyak Rp 25.000,- per bulan, yang dibangun secara bergilir. Artinya secara umum rumah yang ada di Dusun Cigebang sudah berciri rumah sehat.

Selain pohon kelapa yang diakses secara bagi hasil, 70\% mengelola lahan sawah yang luasnya bervariasi antara 1 sampai dengan 7 patok $(1$ patok $=400$ meter persegi), dengan hasil panen rata-rata per patok mencapai 100 sampai dengan 150 per patok tergantung jenis lahan. Di lahan perkebunan rata-rata hasil panen berkisar antara 80-120 kg sedangkan di lahan sawah antara $150 \mathrm{~kg}-200 \mathrm{~kg}$. Tabungan disimpan dalam bentuk ternak domba, dan sapi yang sewaktu-waktu dapat dijual apabila ada kebutuhan mendesak, seperti: membeli sepeda motor secara kredit, memperbaiki rumah dan menyekolahkan anak.

Beberapa penyadap yang memiliki lahan relatif luas (lebih dari 7 patok) terkadang meninggalkan pekerjaannya sementara waktu pada saat musim tanam dan panen padi. Walaupun resiko adalah pohon kelapa menjadi "paleg" karena manggarnya berhenti menghasilkan nira. Untuk memulihkan diperlukan waktu antara 2-3 bulan. Hampir semua pengrajin mengatakan bahwa penyadap lebih menguntungkan daripada usahatani padi, karena menyadap mendatangkan penghasilan setiap hari (lebih rutin). Dari satu kedusunan Cigebang sebanyak $250 \mathrm{KK}$ dan yang menyadap 30 pengrajin gula kelapa. Dari 30 orang pengrajin, 21 rumahtangga diantaranya sebagai petani padi.

Bukan hanya uang yang dipergunakan sebagai alat tukar. Pengrajin kelapa merasa tentram hidupnya manakala memiliki cadagang pangan berupa beras, yang sewaktu-waktu dapat dijual kepada pedagang apabila ada kebutuhan mendesak pada saat musim hajatan. (khitan maupun menikahkan). Sekalipun bertani, pekerjaan sebagai pembuat gula kelapa dianggap sebagai pekerjaan utamanya, karena menghasilkan uang (secara finansial) lebih teratur, lebih tentu dan dapat dipergunakan untuk mencukupi kebutuhan keluarga selain konsumsi sehari-hari (misal: menyekolahkan anak, memperbaiki rumah, membeli perabotan rumah seperti meja, kursi, lemari hingga membeli domba). Berbeda dengan bersawah yang hanya bisa dilakukan 1 kali dalam setahun (padi gogo), menyadap bisa dilakukan sepanjang tahun, walaupun nira dimusim hujan kualitasnya lebih rendah daripada di musim kemarau. (gula kelapa hasil cetakan di musim hujan lebih cepat mencair). Secara umum modal fisik yang dimiliki tergolong cukup (sedang).

\section{Identifikasi Social Capital}

Modal sosial menurut Fukuyama (1995) mencakup unsur kepercayaan (trust), jaringan (network) dan norma. Jaringan yang terbina antara pengrajin dan pedagang pengumpul sangat kuat. Pengrajin memberi sebutan pada pedagang pengumpul "bos". Hampir setiap pengrajin gula kelapa memiliki bos masing-masing. Pengrajin gula kelapa yang secara ekonomi sudah settle, jenderung memiliki ikatan dengan bos secara tunggal (satu bos), sebaliknya dengan penyadap yang lebih rentan memiliki bos lebih dari satu orang bahkan mencapai 5 orang.

Selain hubungan ekonomi (jual-beli), antara "bos" dengan pengrajin gula juga terjalin hubungan sosial. "Bos" selalu hadir sebagai "pahlawan" di saat saat dibutuhkan oleh pengrajin, karena "bos" berusaha memenuhi kebutuhan penyadap mulai dari uang, beras, menyediakan material rumah (pasir, semen, batu bata) untuk membangun rumah dengan besar pinjaman antara Rp 300.000,- hingga 7 juta rupiah. Artinya sistem pembayaran dilakukan dengan system persekot dan dilunasi dengan menjual gula kepada "bos". Hutang-hutang pengrajin gula kelapa dilunasi dengan cara mencicil, namun harga beli Rp 500,- bos lebih rendah daripada harga di pasaran apabila pengrajin gula kelapa memiliki hutang. Pengalaman Bu Sumiati selama ini pinjam dengan nilai berapapun selalu diberikan oleh "bos". Pengrajin yang sudah settle secara ekonomi dan hasil sadapannya tinggi selalu diberikan berapapun pinjaman yang dibutuhkan oleh bos. Umumnya pengrajin menggunakan penghasilan dari menyadap sebesar Rp 60\% untuk mencicil hutang pada bos dan $40 \%$ untuk memenuhi kebutuhan seharihari.

Uraian di atas menunjukkan bahwa hubungan antara "bos" dengan pengrajin gula kelapa bukan didasari ekonomi semata, namun juga hubungan sosial. Hubungan ekonomi selalu dilakukan secara kontraktual (misal: peminjaman uang dilakukan pencatatan oleh "bos") bukan karena azas kekurangpercayaan, atau trust diantara keduanya melemah namun karena pemahaman agama keduanya baik dimana hutang piutang harus dicatat.

Saling bantu antar warga dilakukan pada saat ada acara terkait dengan siklus kehidupan manusia (melahirkan, khitan, menikahkan hingga kematian). Waktu ada warga yang hajatan, warga akan datang dengan membawa beras, mie, minyak, kue kering atau basah. Semakin dekat hubungan antara warga yang hajatan dengan warga lainnya, maka "antaran" yang dibawanya semakin banyak. Sedangkan saling bantu dalam pembuatan rumah umumnya pada saat pemasangan atap (genteng), usuk, reng yang dilakukan secara gotong royong tanpa upah. Jadi si pemilik rumah hanya membayar tukang saja, artinya hampir di setiap segi kehidupan pengrajin gula, modal sosial masih sangat tinggi. Modal sosial yang tinggi inilah yang membuat rumahtangga pengrajin gula kelapa mampu bertahan dalam himpitan ekonomi sekalipun.

Hasil observasi peneliti setelah mengikuti keseharian penyadap nira kelapa, ada rasa puas dengan hasil kerja sebagai pengrajin gula kelapa. Sekalipun anak-anak tidak ada yang meneruskan usaha sebagai pengrajin gula, namun pengrajin gula kelapa masih yakin akan adanya generasi penerus yang masih mau tinggal di kampung dan meneruskan usaha sebagai pengrajin gula kelapa. Hampir semua pengrajin (pasangan suami istri) akan terus menyadap hingga secara fisik tidak kuat. Terlebih apabila ada anak seorang penyadap yang masih belum menikah. Ukuran kemandirian seorang anak dinilai apabila seorang anak telah menikah dan memiliki usaha sendiri (mandiri) secara ekonomi.

\section{Analisis Gender dalam Rumahtangga Pengrajin Gula Kelapa}

Pembagian kerja dalam rumahtangga pengrajin gula kelapa suami dibantu anak laki-laki bertugas menyadap kelapa dan mengangkut nira sedangkan istri terkadang dibantu anak perempuan bertugas memasak nira hingga mencetak gula. Menyadap rata-rata dilakukan pada pukul 06.00 sampai dengan pukul 10.00 wib untuk menurunkan nira dan mengganti jaligen (tempat penampung nira) dan pada pukul 14.00 sampai dengan 16.00 wib kembali ke kebun kelapa untuk memotong manggar agar nira dapat keluar dengan lancar. Proses memasak nira hingga mencetak gula memakan waktu rata-rata 5 jam. Namun 
di musim penghujan proses memasak nira lebih lama (6 jam) karena kualitas nira yang umumnya lebih rendah. Pembagian kerja selengkapnya dapat dilihat pada Tabel 5.

Hasil penjualan gula umumnya dipegang oleh para istri, namun apabila ada kebutuhan yang besar (contoh: memperbaiki rumah, menyekolahkan anak, membeli kendaraan bermotor) diputuskan secara bersama antara suami dan istri. Artinya penggunaan uang hasil sadapan dimanfaatkan secara setara antara suami dan istri.

Tabel 5. Pembagian Kerja Dalam Pembuatan Gula Kelapa (60 pohon)

\begin{tabular}{|c|c|c|c|}
\hline \multirow{2}{*}{$\begin{array}{l}\text { mint } \\
\text { maty }\end{array}$} & \multicolumn{2}{|c|}{ Hmatentil } & \multirow{2}{*}{ 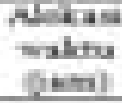 } \\
\hline & Lis & inmpin & \\
\hline 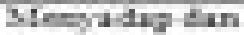 & & & \\
\hline 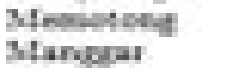 & 1 & & 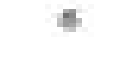 \\
\hline Mratin & tit & & 01 \\
\hline 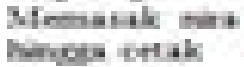 & & 2 & H \\
\hline Mirghrat & $\mathbf{z}$ & & as \\
\hline 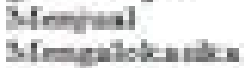 & & $\mathrm{t}$ & 푸 \\
\hline 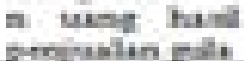 & 4 & 4 & - \\
\hline
\end{tabular}

Dari Tabel 5 terlihat bahwa dari alokasi waktu, pembagian kerja antara laki-laki dan perempuan relatif setara (samasama mencurahkan waktu 6 jam per hari). Demikian juga dengan pemanfaatan uang hasil penjualan gula dilakukan secara setara. Hal ini sesuai dengan Blood (1972) bahwa pada keluarga lapisan bawah peran suami dan istri relatif seimbang. Pada beberapa kasus rumahtangga penyadap nira yang lain (pasangan Bapak Ipit-Bu Sumiati), istri juga berperan sebagai pengangkut nira, sedangkan suaminya hanya menyadap pohon kelapa dan memotong manggar kelapa. Selain membantu dalam pengangkutan nira dan membuat gula kelapa hingga menjualnya, perempuan pulang dari kebun kelapa ke rumah sambil membawa kayu bakar sebagai bahan bakar untuk memasak di rumah. Hampir semua rumahtangga di Dusun Cigebang juga berperan sebagai pengangon ternak sapi dan domba.

\section{KESIMPULAN}

Dari analisis pengelolaan kelima modal atau asset rumahtangga tersebut, modal manusia (human capital) masih perlu ditingkatkan. Pendek kata, pengrajin gula kelapa secara fisik harus sehat agar mereka tetap bisa menjalankan aktivitas ekonominya. Akibat dari pendidikan yang rendah, berpengaruh pada pengetahuan proses pemasakan nira. Semula sebagai bahan pengawet nira dipergunakan bahan alamai berupa: kapur dan kayu nangka yang dikeringkan, namun kini semua pengrajin gula menggunakan bahan kimia bernama Sodium Metabisulfit untuk mengawetkan nira agar tidak cepat basi. Sekalipun penyadap tahu, namun tidak bisa menghindarinya demi keuntungan secara ekonomi.

Keluarga dan komunitas pengrajin gula kelapa memanfaatkan sumberdaya baik individu maupun keluarga dalam memanfaatkan kelima modal (manusia, alam, fisik, finansial, dan sosial) sehingga resiliace-nya besar dalam menghadapi perubahan lingkungan (fisik dan sosialnya), terlebih menghadap tuntutan-tuntutan dan kewajiban-kewajiban dari perusahaan. Individu atau keluarga mampu beradaptasi dengan menjalin hubungan (jaringan) dengan beberapa "bos", menanam tanaman pangan lain (singkong dan pisang) serta mengolah singkong sebagai pengganti nasi. Individu yang "keluar"" dari komunitas pengrajin gula untuk bermigrasi ke Jakarta hanya anak-anak pengrajin yang masih berusia muda (15-28 tahun). Leader atau pemimpin tidak terlalu berpengaruh karena semua pengrajin gula kelapa berusaha secara mandiri (sendiri-sendiri) tidak secara berkelompok.

Dari pembagian kerja dan pengambilan keputusan, gender dalam rumahtangga pengrajin gula kelapa cenderung seimbang antara peran laki-laki (suami) dan perempuan (istri). Bukan hanya dilihat dari alokasi waktu, namun juga pemanfaatan uang hasil penjualan gula.

\section{DAFTAR PUSTAKA}

Chambers, R and Conway, G.R. 1991. Sustainable Rural Livelihoods and Landscapes: Practical Concepts for the 21 st Century. IDS Sussex: IDS Discussion Paper No. 296.

De Haan, L.J. 2000. "Globalization, Localization, and Sustainable Livelihood”, Sociologia Ruralis, Vol. 40, No. 3, pp. 339-365.

Ellis, F. 2000. Rural Livelihoods and Diversity in Developing Countries. Oxpord: Oxford University Press.

Fakih, Mansoer. 1997. Analisis Gender dan Transformasi Sosial. Yogyakarta: Pustaka Pelajar.

Miles, Matthew dan A. Michael Huberman. 1992. Analisis Data Kualitatif: Buku Sumber Tantang Metode-Metode Baru. Jakarta: UI Press.

Megawangi, Ratna. 1999. Membiarkan Berbeda. Bandung: Mizan.

Rahmawati, Ika. 2003. Modul Analisis Gender. Jakarta: The Asia Foundation.

SK Gubernur Jawa Barat No. 561/Kep.1636-Bangsos/2014). Daftar UMK 2014 di Jawa Barat. http://m.antaranews. com/berita/406211/daftar-umk-2014-di-jawa-barat 


\section{Lampiran 1. Alur proses pembuatan gula kelapa}

1. Penyadap memanjat pohon kelapa, kemudian menyalin nira hasil sadapan dari jerigen wadah nira ke jerigen 5 liter. Setelah itu tandan kelapa ("sintung") diikat dan dipapras/dilukai untuk merangsang keluarnya nira. Setelah nira diambil, jerigen penampung diteteskan larutan natrium bisulphite (biang gula) 2-3 tetes agar larutan nira yang ditampung tahan lama. Setelah proses selesai penyadap turun dari pohon kelapa.

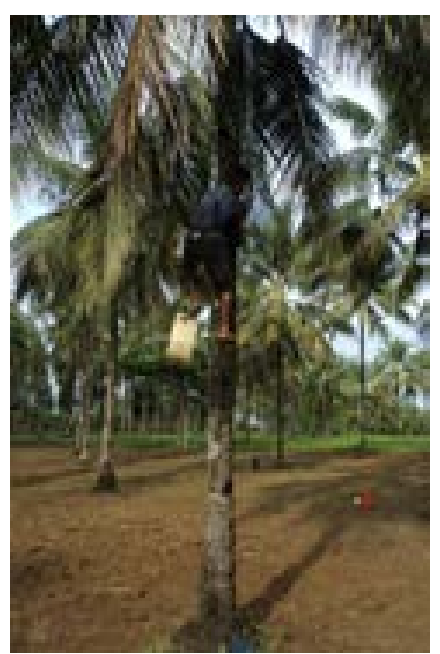

5. Hasil rebusan (larutan gula) kemudian diturunkan dari tungku untuk didinginkan, sambil diaduk-aduk selama 30 menit sampai mengental.

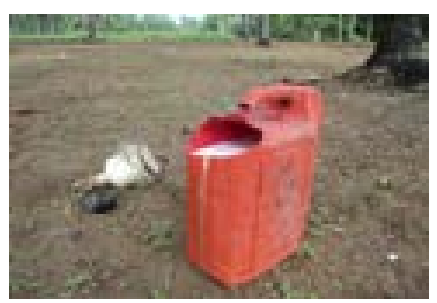

6. Setelah gula mengental, larutan diambil dengan gayung dan dituangkan ke dalam cetakan bambu dan dibiarkan selama 20 menit.

7. Kemudian gula dilepas dari cetakan dan dikemas dalam plastik (10 $\mathrm{kg} /$ plastik).
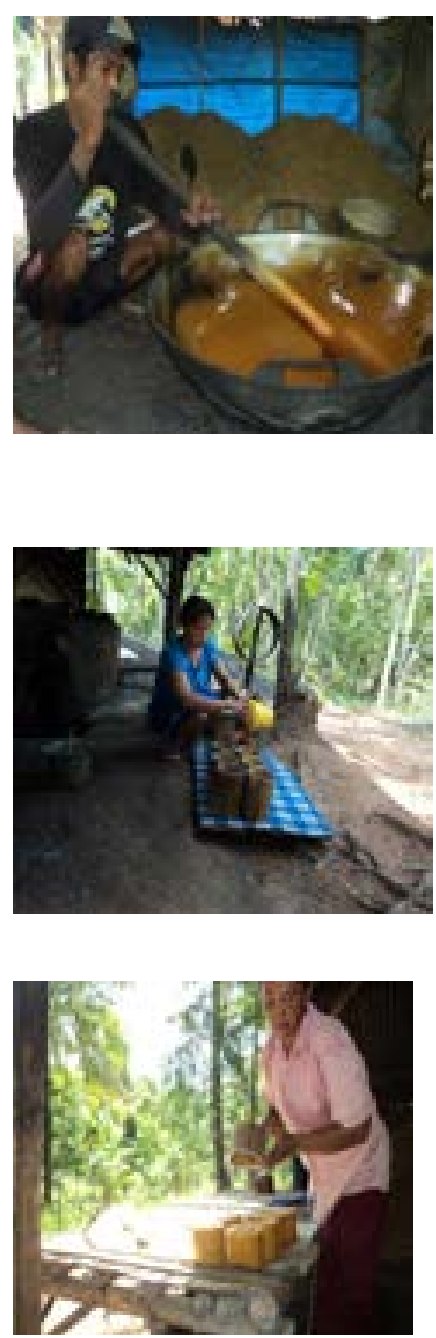

3. Sebelum nira direbus, diletakkan anyaman bambu berbentuk silinder didalam kuali yang tingginya lebih dari tinggi kuali, fungsinya agar larutan nira pada saat mendidih tidak tumpah.

4. Proses memasak nira dilakukan di "heunca". Nira direbus dalam kuali sekitar 6 jam di atas tungku. 30 menit sebelum masak, hasil rebusan nira dicampur dengan parutan kelapa (1 butir) yang diberikan secara bertahap agar larutan nira menggumpal.
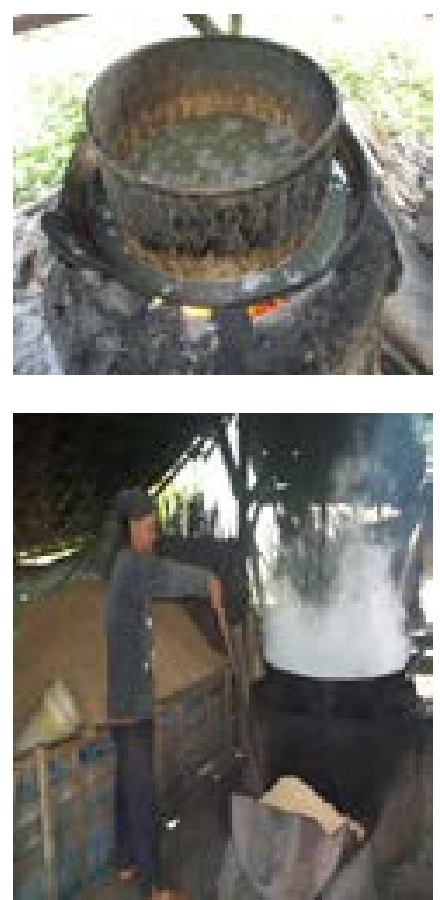
